\title{
Food for Thought ... on Food Safety Testing
}

\author{
Thomas Hartung ${ }^{1}$ and Herman Koëter ${ }^{2}$ \\ ${ }^{1}$ EU JRC, IPSC, TRiVA unit, Ispra, Italy; ${ }^{2}$ Former Deputy Executive Director and Director of Science, European Food \\ Safety Authority (EFSA), Parma, Italy
}

More than any other consumer product range, food represents an emotional issue with a strong cultural dimension. In a Eurobarometer survey of 2002, 89\% of the Europeans interviewed considered food safety to be very important; interestingly $80 \%$ considered animal welfare to be very important in the same survey. Food also has an enormous economic impact on society, with the European food and drink industry boasting a turnover of about 600 billion $€$ (i.e. $15 \%$ of the manufacturing output of Europe) and 2.6 million employees (Holland and Pope, 2004). This still excludes the agricultural sector, which produces 220 billion $€$ of products and provides 7.5 million people with jobs. In an often quoted speech made in 1962, John F. Kennedy declared consumer safety a fundamental right. Due to globalisation (roughly 50\% of our food is nowadays imported) and condensation of the industry, in particular of food retailers, to a rather small number in recent years, an asymmetry of information with respect to the safety and control of food products has developed which requires international attention

\section{Consideration 1: The general public is not aware of the extent of animal experimentation carried out for food products}

According to the official statistics (European Commission, 2007), food related issues appear to consume only a small number of experimental animals: About the same number of animals are used for the testing of food additives for humans as for cosmetics, i.e. $0.4-0.5 \%$ of all experimental animals in toxicology, which represents $10 \%$ of all experimental animal use. This small percentage arises not from the limited testing of food additives but from the small number of new food additives developed and the requirement to test only the new additives, not the products. Hence animal use to test the safety of animal feed additives is already 10-times higher $(3.3 \%)$, largely because for several types of animal feed additives (such as grow factors) all products containing these additives should be tested. The testing of plant protection products (PPP, i.e. fungicides, herbicides, insecticides etc.) makes up $9.5 \%$ of all toxicological animal use, which is just about the same percentage of animals as that used to test industrial chemicals $(9.4 \%)$. This is a remarkably high number, since only about 8 new PPPs enter the market each year. However, since PPPs are intended to be biologically active (and destructive) the testing requirements are the most stringent and require substantial animal use for each PPP. Furthermore, of the 353 thousand tons of PPP sold in Europe per year (Eurostat. Food, 2006), a substantial percentage (estimates range from 20 to $40 \%$ ) is likely to be replaced in the coming years by better products (with less impact on the environment or a lower chance of inducing antimicrobial resistance in the exposed pests) and as a result of the expected revision of pesticide thresholds and a hazard-based restriction of use. It is thus likely that animal use in this field will increase in the next years in order to enable the marketing of substitutes.

While animal use for experimental purposes is covered by European statistics, some testing for the safety of products and for diagnostic purposes is not. One example is the testing of botulinum toxin: This issue was addressed in an ICCVAM/NICEATM/ECVAM Scientific Workshop on Alternative Methods to Refine, Reduce, and Replace the Mouse $\mathrm{LD}_{50}$ Assay For Botulinum Toxin Testing (November 13-14, 2006, Silver Spring, MD; http://iccvam.niehs.nih. gov/docs/biologics-docs/BoNTwkshprept.pdf): Though it is hardly relevant in the EU as a potential food poison, 17 test laboratories carry out botulinum toxin determinations in the US alone (Susan Maslanka (Centers for Disease Control and Prevention, USA), http://iccvam.niehs.nih.gov/methods/biologics/ botdocs/biolowkshp/wkshp_pres.htm), and they use 48 mice per sample (Shashi Sharma (U.S. Food and Drug Administration, CFSAN), same website). Although no numbers are known, this might be an indication of some animal use associated with severe suffering.

A further example is the assessment of marine biotoxins that are absorbed by shellfish. These occasionally prove lethal for humans (Anderson et al., 1993), but more often result in nausea and diarrhoea. The regular controls are still to a large extent performed using a mouse assay despite available (non-validated) alternatives (Hess et al., 2006). No animal use numbers are available, but some experts in this field estimate the number of mice used to be between 350 and 700 thousand per year. The ECVAM workshop was one of the most effective of its kind: It led to proposed changes of mouse group sizes ( 3 down to 2 ) and the Community Reference Laboratory initiated a validation study. A subsequent EFSA opinion to lower the required limit of detection below what the mouse assay can achieve practically forces the use of alternative methods. In addition, EFSA 
has subsequently adopted two opinions on particular groups of marine biotoxins and recommended in both opinions that the evidence available at this moment suggests that liquid chromatographymass spectrometry/mass spectrometry (LC-MS/MS) based methods have the greatest potential to replace the mammalian assays (EFSA, 2007a; EFSA, 2008a). As a result of these activities one may expect that animal testing for marine biotoxins will strongly decrease in the coming years.

The area of food allergy is receiving increasing attention. About 200 food allergens are known (although the "big 8" are responsible for $90 \%$ of clinical cases). There is increasing interest in possible allergenicity, for example of genetically modified organisms (GMO). Food and products have already been withdrawn from the market because of such concerns (Houghton et al., 2008). Animal models exist (Houbena et al., 1997; McClain and Bannon, 2006) also in larger animals (Helm et al., 2003) but have not made it to routine tests among others because of their limited predictability for humans. Currently this issue is being addressed by a working group of the EFSA GMO Panel. Food allergies are already difficult to diagnose in humans: The allergen often only forms during digestion (thus the raw product often induces no skin reaction), and the symptoms are delayed. With the differences in the digestive system of rodent laboratory animals and also known differences of individual strains (being in-bred and by far not reflecting the variability of human immune reactions), no animal model is likely to reflect a human population risk for food allergy. Approaches which may work in the future include proteomics and metabonomics of in vitro models rather than animal tests.

There is likely considerably more animal testing of products, given that for example today a cow provides raw materials for 50,000 different products (Ansell and Vogel, 2006). Table 1 summarises some estimates of health threats and respective animal testing estimates. Remarkably, the awareness that experimental animals are used to a considerable extent to ensure the safety of our food and animal feed is not common knowledge. But animal welfare concerns extend also to the farm animals: $60 \%$ of the EU population is worried about the welfare (Eurobarometer, 2006) of the 86 million farm animals in Europe (Eurostat. Food, 2006). The latter number is a multiple of the about 12 million laboratory animals used per year. EFSA's opinions on welfare issues of food-producing animals range from transport of animals, housing and breeding conditions to the humane killing of these animals and are widely appreciated by animal welfare groups. Still, pressure on food producers and retailers could be expected once NGOs realise that our daily food is linked to considerable animal use.

\section{Consideration 2: The rigorous scientific approach to assure food safety can be a role model for other areas}

Food safety problems are as old as mankind: One of the first recorded cases occurred in AD 944 when about 40,000 people died in Southern France due to ergotism, the long-term ergot poisoning resulting from the ingestion of the alkaloids produced by the Claviceps purpurea fungus, which infects rye and other cereals (Knowles et al., 2007). The need for food safety regulation is likewise very old, e.g. the British Impure Food

Tab. 1: Food safety concerns and their contribution to animal testing

\begin{tabular}{|c|c|c|c|c|}
\hline Safety concern & $\begin{array}{l}\text { Likely associated } \\
\text { deaths in EU per year }\end{array}$ & $\begin{array}{l}\text { Estimated animal use } \\
\text { for research } \\
\text { and testing } 2008\end{array}$ & $\begin{array}{l}\text { Trend for animal } \\
\text { numbers }\end{array}$ & Remarks \\
\hline Microbial contamination & $10,000-100,000$ & $10,000-100,000$ & $\leftrightarrow$ & Only academic research \\
\hline Marine biotoxins & $100-1,000$ & $300,000-700,000$ & $\downarrow \downarrow$ & $\begin{array}{l}\text { Alternatives available } \\
\text { and under validation }\end{array}$ \\
\hline Botulinum toxin & $10-100$ & $1,000-10,000$ & $\downarrow \downarrow$ & Alternatives available \\
\hline Food allergy & Low & $1,000-10,000$ & $\uparrow \uparrow$ & $\begin{array}{l}\text { No sufficient model } \\
\text { available }\end{array}$ \\
\hline Chemical contaminants & Low & $1,000-10,000$ & $\leftrightarrow$ & Academic research \\
\hline Food additives toxicity & Low & $1,000-10,000$ & $\leftrightarrow$ & Few new products \\
\hline GMO & none & $1,000-10,000$ & $\uparrow$ & $\begin{array}{l}\text { Increasing testing } \\
\text { requirements }\end{array}$ \\
\hline Positive health effects & n.a. & $10,000-100,000$ & $\uparrow \uparrow$ & $\begin{array}{l}\text { So far mostly } \\
\text { academic research }\end{array}$ \\
\hline Low nutritional value & $1,000,000-10,000,000$ & $10,000-100,000$ & $\uparrow$ & Academic research \\
\hline Plant protection products & Low & $150,000-200,000$ & $\uparrow$ & $\begin{array}{l}\text { New legislation prompts } \\
\text { substitutes }\end{array}$ \\
\hline
\end{tabular}


Act dates back to 1226 and the German "Reinheitsgebot" for beer to 1516. Most European countries introduced more extensive regulations between 1860 and 1890 (Ansell and Vogel, 2006). European legislation started in 1962 with a Directive on food colourants. Today food worth about 430 billion $€$ is traded between European member states (Holland and Pope, 2004) and, due to the principle of mutual recognition, lawfully produced products from one member state are marketable in all.

But there is also a downside to good food risk management: It has been called "the paradox of progress" (Houghton et al., 2008) and relates to the perception of risks: increasingly lower detection levels of food contaminants, stricter standards, quality controls and monitoring procedures inevitably lead to an increasing number of food safety alerts. These, in turn, may easily result in a higher perception of risk in the consumer and, consequently, in a loss of consumer confidence. It is not unimaginable that a loss of confidence would trigger more testing.

An example of progress in risk assessment originating from the food area is the concept of a threshold of toxicological concern (TTC) (Munro et al., 2008). Its possible role in the evolution of toxicology has been discussed previously (Hartung and Leist, 2008; Koëter, 2008). The idea is remarkably simple: Very low amounts - very low risk, very low amounts and noncritical structural features - negligible risk. From a large database of substances, a general threshold of regulation (TOR) of $1.5 \mu \mathrm{g} /$ day was developed by the FDA for packaging migrants (i.e. contaminants which pass from the package material into the food), regardless of possible structural alerts. In Europe, this approach was further developed to differentiate between three chemical classes by setting separate thresholds of toxicological concern (TTC) of 1,800, 540 and $90 \mu \mathrm{g} /$ day, respectively (Kroes et al., 2005). This is used internationally for flavouring substances, but the approach is currently being considered for other areas of chemical assessment, such as packaging materials and food contaminants. Especially for cosmetic ingredients but also for pesticide risk assessment, this offers opportunities to meet the legislative challenge of phasing out animal experimentation (Hartung, 2008, Koëter 2008).

Similarly, the food area was the first to adopt elements from evidence-based medicine for risk assessment (McCullum et al., 2005), as is currently being pursued for toxicology (Hoffmann and Hartung, 2006; http://www.ebtox.org).

Whereas the safety testing of food and feed ingredients is not different from any other area of chemical assessment, whole and novel food safety testing in animals is quite limited, because normally the typical high-dose approach cannot be applied, because the maximum tolerated doses are typically limited to $5-10 \%$ of the diet to avoid nutritional imbalance. Given the normally low toxicity of whole foods, such low doses would make it impossible to establish dose-response curves and, hence, to characterise the hazard profile. Therefore, whole foods are normally assessed by comparing their molecular characterisation to that of already accepted foods and by focussing the testing on those components which are different. Furthermore, close surveillance of consumers following controlled exposure is possible. Thus, at least in principle, control is possible after marketing of novel foods.

As a consequence of various food scandals a very rigorous, science-based regulation emerged with the European General Food Law (regulation $178 / 2002$ ) of 2002. It formed the basis for creating the independent European Food Safety Authority (EFSA). According to paragraph 6 of the regulation, risk assessments have to be based on scientific evidence and must be independent, objective and transparent. The following paragraph introduces the precautionary approach principle. Furthermore, a rapid alert system for food and feed safety problems has been created. Thus, the law does not only foresee a rigorous risk assessment, but also acknowledges that risks will remain (e.g. through adulterated food, contaminations, etc.) and that post-market surveillance of products is important. Other areas could benefit from such an approach, but as discussed earlier in this series of articles, there is a tendency to close the books after a risk assessment is completed and to ignore the fact that intentional or unintentional human interventions may alter the assessed risks on which the risk management was based.

\section{Consideration 3: Future food safety testing has to go beyond testing of ingredients and microbiological and chemical contamination testing}

Consumers are aware of food safety (Fig. 1) as something which can affect them personally (42\% according to Eurobarometer 2006): $63 \%$ are worried about pesticide residues, $62 \%$ about viral contamination like avian influenza, $62 \%$ about antibiotics and hormones in meat, $62 \%$ about hygiene outside home, 59\% about contaminants like mercury and dioxins, 58\% about GMO, 57\% about food additives, $53 \%$ about BSE and $49 \%$ about chemical substances formed during the cooking process. Considerably less importance is given to the far more threatening health risks, i.e. putting on weight (48\%), food allergies (43\%) and, in particular, poorhygienic handling of foods at home $(32 \%)$. Experts consider consumers to be inadequately aware of these significant health risks (Houghton et al., 2008), which are in their importance roughly just reverse to the ranking given above. Microbiological risks from poor hygiene are much more serious than those related to food contamination early on in the food production chain, which costs hardly any lives (Knowles et al., 2007). According to Danish data (Lobstein, 2002) on the frequency of food-born diseases, there are about 12,000 cases of Campylobacter infection per million inhabitants; Campylobacter is associated with 24 deaths per 10,000 culture-confirmed cases (http:// www.emedicine.com/PED/topic2697. $\mathrm{htm})$, i.e. up to 14,400 deaths in Europe. For Salmonella he reports approximately 20,000 cases per million inhabitants (Mead et al., 1999 estimated 5,000 for the USA), with a lethality of $0.04 \%$, i.e. about 4,000 deaths in Europe. Notably, the number of reported cases (750 per 
million in 1996 down to 450 in 2003 for EU) is considerably lower than the real number (Mead et al., 1999 estimated a factor of 37). These high numbers of common gastrointestinal infections which get hardly any attention from risk managers contrast sharply with the comparably few cases of mad cow disease related human deaths from the novel variant of Creutzfeld-Jacob disease, which peaked in 2000 with 29 cases and receded to about 20 deaths per year (Eurostat. Food, 2006). However, risk management of these and other infectious disease hazards do not impact on animal testing.

This might be different for another category of emerging, food-born health risks: It is increasingly recognised that nutritional value impacts on health, e.g. diabetes, caries, cancer and cardiovascular diseases. The WHO calculated in 2000 for the EU region that more than 130 million disability-adjusted life years (DALY's) are lost annually to a broad variety of diseases: for 55 million of these nutritional factors play an important role and in another 50 million they contribute to the loss (Lobstein, 2002). In 1997 the Swedish National Institute of Public Health calculated a $9 \%$ contribution of nutrition to ill health, which is exactly as high as the contribution of smoking (Lobstein, 2002). Both animal models and human studies might be considered to test for pro-diabetic or pro-atherosclerotic effects of food and nutrition, but so far this has been limited to academic research rather than applied as a standard testing regimen. However, it is not unlikely that such standard testing would form the basis for any future "nutritional policy" regulating the health value of food (Margettsa et al., 2001; Caraher and Coveney, 2004). Furthermore, alternatives to notoriously "bad" nutrients (e.g. saturated fat, sugar) have been developed (such as artificial sweeteners) or are being developed (such as fat replacements), which are subject to extensive animal testing before being allowed on the market.

Going one step further, i.e. to health claims of food or so-called "functional food" with intended health effects, we are approaching a quasi-pharmaceutical area. To prove efficacy in addition to

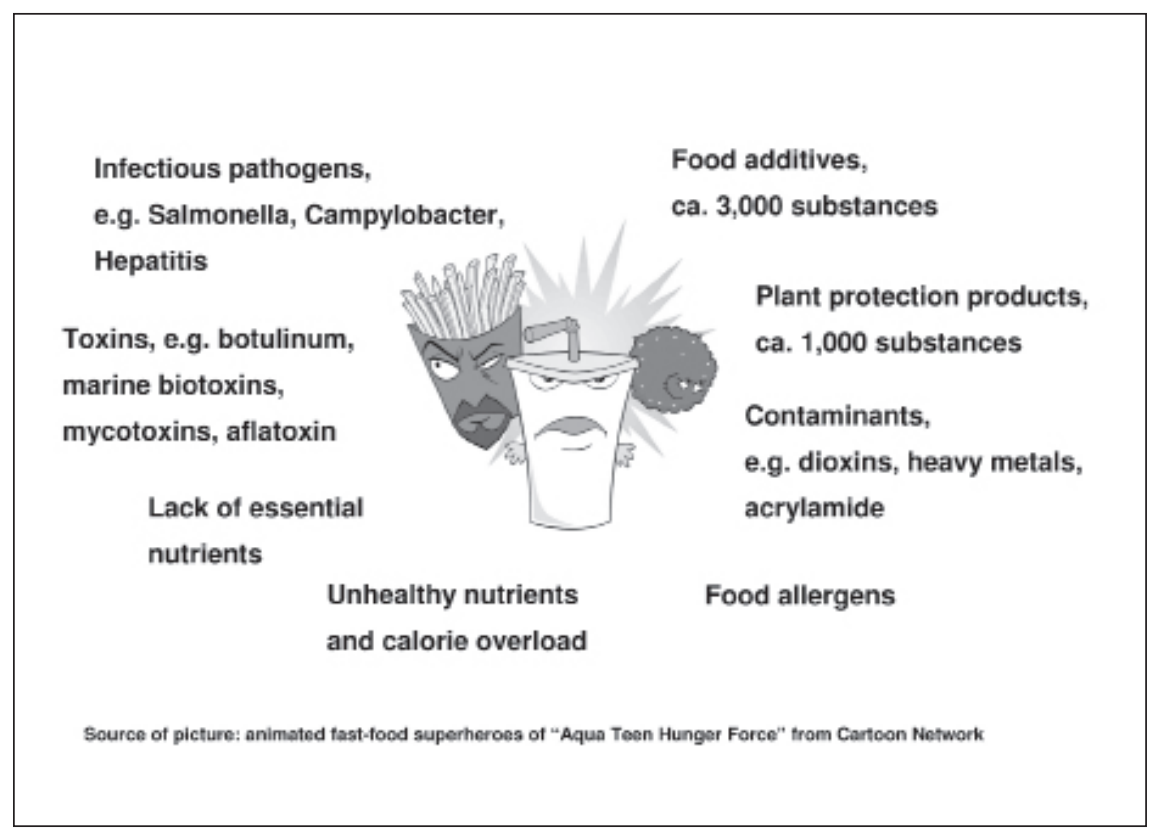

Fig. 1: Food safety concerns

safety, a test scheme analogous to the one for pharmaceuticals might be envisaged (Monro, 2000; Katan and Roos, 2003; Przyrembel and Kleiner, 2008; Renwick and Walker, 2008). EFSA's Nutrition Panel has already developed guidance with respect to the preferred data that should be made available to justify the proposed health claims (EFSA, 2007b). Although the dossiers submitted to prove efficacy that are currently being received by EFSA for assessment are still relatively slim and refer mainly to human data and theoretical explanations, they already amount to several thousands. It is expected that, following the rejection of claims insufficiently supported by evidence, more robust applications will follow, which may well include animal testing. However, similar to any cosmetics, strong biological effects are not intended, because the boarder to drugs would be crossed.

Another new area of interest is that of herbal preparations for human consumption. Although this area is largely not regulated, which means that there is no requirement for registration, data submission and risk assessment, these products are generally considered by consumers as safer than the well-regulated (chemical) food additives. Unfortunately, today herbal preparations are hardly defined, their composition is unclear and often misleading and their assumed health claims are not supported by any evidence. EFSA has addressed this issue in recent years and has developed guidance for the harmonised risk assessment of such products (EFSA, 2008b). Inevitably, animal testing, though limited, is likely to become an essential part of the proposed risk assessment approach.

\section{Consideration 4: Animal testing must not be abused to create non-tariff barriers or delay marketing of products}

The risk approach for GMOs adopted by EFSA is based on a case-by-case assessment depending on the crop, the introduced traits, the intended use and the receiving environment. It is a tiered approach whereby the available information determines the requirements for further steps in the risk assessment. The assessment of GMOs, as for whole and novel foods, is based on a comparative principle, whereby the food being assessed is compared with its traditional equivalent that has an accepted level of safety, often based on a history of safe use. If needed, 
tailor-made studies are requested because the hazard characterisation of novel foods, including GMOs, requires special considerations for their safety. As an example, the need for a 90-day animal feeding trial depends on the evidence already available and additional data needed to assess the safety of the GMO. In practice, however, certain EU countries with a history of consumer aversion against any GMO tend to require more studies (in particular long term animal studies) for reasons unrelated to a scientific need or uncertainty in the hazard characterisation. This practice, often used as a strategy to delay approval for import or cultivation, has already resulted in unnecessary animal testing and is likely to trigger many more animal studies as a barrier to delay or avoid marketing, rather than for risk assessment purposes.

\section{Consideration 5: The food area is predestined for private-public partnerships complementing limited regulatory involvement}

The food area has undergone a remarkable concentration in recent years While the 10 biggest retailers in Europe covered less than $20 \%$ of the market in 1989 , this rose to more than $45 \%$ in 2002 (Ansell and Vogel, 2006). Today, five major retailers account for $80 \%$ of all food shopping in France and four retailers for $80 \%$ in Germany (Caraher and Coveney, 2004). In some cases, large retailing chains have installed quality assurance schemes that go beyond the legal requirements. This is part of a broad strategy to promote consumer trust, minimise liability and achieve competitive advantage (Houghton et al., 2008). Global coalitions of food producing industry and retailers have formed to set food standards, such as Eurepgap/Globalgap (http://www.globalgap.org) and the Global Food Safety Initiative "GFSI" (http://www.ciesnet.com/2-wwedo/2.2programmes/2.2.foodsafety.gfsi.asp). In addition, the food-producing industry has established scientific institutions to address food technology and safety issues jointly with academia and govern- ment experts. The International Life Sciences Institute (ILSI) with branches in North America, Europe and Asia is an example of such an excellent cooperation. The food industry is also active in the European Technology Platforms (ETP), partly financed by the European Commission (DG Research, Framework Programme 7), in particular in the Programme Food for Life (http://etp.ciaa. be/asp/home/welcome.asp).

All these initiatives might be leading toward a new type of public/private partnership, where legislation defines minimum standards but jointly higher voluntary standards are developed and promoted. Such a model would be considerably more flexible to incorporate new approaches.

\section{References}

Anderson, D. M., Galloway, S. B. and Joseph, J. D. (1993). Marine biotoxins and harmful algae: a national plan. Woods Hole Oceanographic Institution Technical Report, http://hdl.handle.net/1912/614

Ansell, C. and Vogel, D. (2006). What's the beef? The contested governance of European food safety. The MIT Press, Cambridge Massachusetts.

Caraher, M. and Coveney, J. (2004). Public health nutrition and food policy. Public Health Nutr., 7, 591-598.

EFSA (2007a). Marine biotoxins in shellfish - okadaic acid and analogues - Scientific Opinion of the Panel on Contaminants in the Food Chain. Adopted November 2007, published January 2008

EFSA (2007b). Final scientific and technical guidance for applicants for preparation and presentation of the application for authorisation of a health claim.

http://www.efsa.europa.eu/EFSA/efsa locale-1178620753812_1178623592471. htm

EFSA (2008a). Marine biotoxins in shellfish - Azaspiracid group - Scientific Opinion of the Panel on Contaminants in the Food Chain. Adopted in June 2008, published in October 2008

EFSA (2008b). Guidance document on the safety assessment of botanicals and botanical preparations intended for use as ingredients in food supplements.

http://www.efsa.europa.eu/ EFSA/efsa_locale-1178620753812_ $1178717026833 . \mathrm{htm}$

Eurobarometer. 238 Risk issues. (2006). http://ec.europa.eu/food/food/ resources/publications_en.htm

European Commission (2007). Report from the Commission to the Council and the European Parliament: Fourth report on the statistics on the number of animals used for experimental and other scientific purposes in the member states in the European Union. $\{\operatorname{SEC}(2005) 45\}$,

http://eur-lex.europa.eu/LexUriServ/

LexUriServdo?uri=CELEX: 52005DC0007:EN:NOT

Eurostat. Food (2006). From farm to fork statistics - statistical pocketbook. http://ec.europa.eu/food/resources/ publications_en.htm

Hartung, T. and Leist, M. (2008). Food for thought $\ldots$ on the evolution of toxicology and phasing out of animal testing. ALTEX 25, 91-96.

Hartung, T. (2008). Food for thought ... on alternative methods for cosmetics safety testing. ALTEX 25, 147-162.

Helm, R. M., Ermel, R. W. and Frick, O. L. (2003). Nonmurine animal models of food allergy. Environ. Health Perspect. 111, 239-244.

Hess, P., Grune, B., Anderson, D. B. et al. (2006). Three Rs Approaches in Marine Biotoxin Testing - the report and recommendations of a joint ECVAM/DG SANCO workshop (ECVAM Workshop 55). ATLA 34, 193-224.

Hoffmann, S. and Hartung, T. (2006). Towards an evidence-based toxicology. Human Exp. Toxicol. 25, 497513.

Holland, D. and Pope, H. (2004). EU food law and policy. The Hague: Kluwer Law International.

Houbena, G. F., Knippels, L. M. J. and Penninks, A. H. (1997). Food allergy: predictive testing of food products. Env. Toxicol. Pharmacol.4, 127-135.

Houghton, J. R., Rowe, G., Frewer, L. J. (2008). The quality of food risk management in Europe: perspectives and priorities. Food Policy 33, 13-26. 
Katan, M. B. and de Roos, N. M. (2003). Toward Evidence-Based Health Claims for Foods. Science 299, 206207.

Knowles, T., Moody, R. and McEachern, M. G. (2007). European food scares and their impact on EU food policy. Brit. Food J. 109, 43-67.

Koëter, H. B. W. M. (2008). ExposureDriven safety assessment strategies. TNO-SAFE Consortium Symposium, Brussels, 31 January-1 February 2008. Weblink: http://www.safeconsortium. org/pageview.asp?structureID=314

Kroes, R., Kleiner, J. and Renwick, A. (2005) The threshold of toxicological concern concept in risk assessment. Tox. Sci. 86, 226-230.

Lobstein, T. (2002). Food policies: a threat to health? Proc. Nutr. Soc. 61, 579-585.

Margettsa, B., Warma, D., Yngvea, A. and Sjöströma, M.(2001). Developing an evidence-based approach to Public Health Nutrition: translating evidence into policy. Public Health Nutrition 4, 1393-1397.
McClain, S. and Bannon, G. A. (2006). Animal models of food allergy: Opportunities and barriers. Curr. Allergy Asthma Rep. 6, 141-144.

McCullum, C., Desjardins, E., Kraak, V. et al. (2005). Evidence-based strategies to build community food security. J. Am. Dietetic Assoc. 105, 278-283.

Mead, P. S., Slutsker, L., Dietz, V. et al. (1999). Food related illness and death in the United States. Emerg. Infect. Dis. 5, 607-625.

Monro, J. A. (2000). Evidence-based food choice: the need for new measures of food effects. Trends Food Sci. Techn. 11, 136-144.

Munro, I. C., Renwick, A. G. and Danielewska-Nikiel, B. (2008). The thresholds of toxicological concern in risk assessment. Toxicol. Lett. 180, 151-156.

Przyrembel, H. and Kleiner, J. (2008). What is a benefit in relation to food consumption? Toxicol. Lett. 180, 7274.

Renwik, A. G. and Walker, R. (2008). Risk assessment of micronutrients.
Toxicol. Lett. 180, 123-130.

Wictome, M., Newton, K. A., Jameson, K. et al. (1999). Development of in vitro assays for the detection of botulinum toxins in foods. FEMS Immunol. Med. Microbiol. 24, 319-323.

\section{Acknowledgement}

The opinions expressed in this article are those of the authors and not necessarily those of the European Commission or the European Food Safety Authority. The valuable input of our (former) coworkers is gratefully appreciated.

\section{Correspondence to}

Prof. Dr. Dr. Thomas Hartung

EU Joint Research Centre

Institute for the Protection and Security of the Citizen

Traceability, Risk and Vulnerability

Assessment (TRiVA) unit

21027 Ispra

Italy

e-mail: Thomas.Hartung@ec.europa.eu 


\title{
Vor- und Nachdenkliches ... zur Sicherheitsprüfung von Nahrungsmitteln
}

\author{
Thomas Hartung und Herman Koëter
}

Nahrungsmittelsicherheit wurde in einer Eurobarometer-Umfrage 2002 von $89 \%$ der Befragten als sehr wichtig eingestuft. Der Öffentlichkeit ist jedoch nicht bewusst, in welchem Ausmass zur Risikoabschätzung von Nahrungsmittelprodukten Tierversuche durchgeführt werden. Zwar ist die Testung von neuen Nahrungsmittelzusätzen für den Menschen relativ selten, doch werden für die Testung von Tierfutterzusätzen und Pflanzenschutzmitteln ca. $13 \%$ aller in der Toxikologie verwendeten Versuchstiere verbraucht. Zudem werden weitere Sicherheitsprüfungen an Tieren, z.B. auf Botulinustoxin, marine Biotoxine oder Nahrungsmittelallergene in den Statistiken nicht erfasst.

Gesetze zur Regulierung der Nahrungsmittelsicherheit begleiten uns schon viele Jahrhunderte. Die heutige, gute Überwachung und die sensitiven Tests führen häufig zu Problemmeldungen, welche aber das Vertrauen der Verbraucher erschüttern statt zu stärken. Die Nahrungsmittelsicherheit übernahm in vielen Fällen eine Vorreiterfunktion, von der andere Bereiche der Sicherheitsprüfung profitieren könnten: Sie führte die ,threshholds of no concern (TOC)" ein und übernahm früh Elemen- te der Evidenz-basierten Medizin. Das Europäische allgemeine Lebensmittelgesetz (Verordnung 178/2002) war die Grundlage zur Errichtung der Europäischen Behörde für Lebensmittelsicherheit (EFSA) und fordert nicht nur eine stringente Risikoabschätzung von Lebensmitteln, sondern erkennt, dass trotz Testung ein Restrisiko bestehen bleibt, und sieht daher eine Überwachung auch nach der Markteinführung vor.

Verbraucher sind besorgt über viele mögliche Gesundheitsrisiken, die von Nahrungsmitteln ausgehen können, doch überschätzen sie diese Risiken im Vergleich $\mathrm{zu}$ viel bedrohlicheren Gesundheitsrisiken wie Überernährung, Lebensmittelallergien und vor allem unhygienischem Umgang mit Lebensmitteln in der eigenen Küche. Das Schwedische Staatliche Institut für Öffentliche Gesundheit berechnete, dass schlechte Ernährung einen gleich hohen Beitrag zu Krankheiten leistet wie Rauchen. Es kann daher erwartet werden, dass weitere Tierversuche oder Studien an Menschen in Zukunft eingeführt werden, um den Nährwert von neuen Lebensmitteln und die Sicherheit von neuen Ersatznahrungsmitteln einzuschätzen. Ferner werden mehr Tierversuche zum Nach- weis der Wirkung von funktionellen Lebensmitteln und zur Risikoabschätzung pflanzlicher Präparationen für den Menschen gefordert werden. Obwohl EFSA angemessene Teststrategien für genetisch modifizierte Organismen festlegt hat, fordern bestimmte Länder häufig zusätzliche, wissenschaftlich nicht rechtfertigbare Tierversuche, um den Import oder den Anbau von GMO zu verzögern.

Der Lebensmittelbereich hat in den letzten Jahren eine gewaltige Konzentration erfahren. Wenige Konzerne teilen sich nun den Löwenanteil des Marktes. Manche haben Qualitätssicherungssysteme installiert, die über die gesetzlichen Bestimmungen hinausgehen, globale Koalitionen haben Standards für Nahrungsmittel festgesetzt, und die Nahrungsmittelindustrie hat wissenschaftliche Institutionen für Lebensmitteltechnologie und Sicherheitsrisiken aufgebaut. Diese Initiativen könnten eine neue, öffentlich-private Partnerschaft einläuten, welche auf der Basis der gesetzlichen Vorgaben freiwillig höhere Standards entwickelt und festlegt. Ein solches Modell wäre ausreichend flexibel, um auch zukünftige Entwicklungen umzusetzen. 